\title{
Relationship between vocational training centres and industrial SMEs in the Basque Country: A regional innovation system approach
}

\author{
Eneka Albizu, Mikel Olazaran, Cristina Lavía, Beatriz Otero \\ University of the Basque Country (Spain) \\ eneka.albizu@ehu.es, mikel.olazaran@ehu.es, cristina.lavia@ehu.es, \\ beatriz.otero@ehu.es
}

Received April, 2011

Accepted September, 2011

\section{Abstract}

Purpose: The aim of this document is to analyse the reach of the relation between vocational training (VT) centres and industrial SMEs in the Basque Country (Spain), and its influence on innovation processes developed by companies.

Design/ methodology/ approach: We employ the conceptual framework offered by the Regional Innovation System (RIS) perspective and the information supplied, on the one hand, by relevant actors within the vocational training system, through in-depth interviews, and, on the other, by the response of industrial SMEs to a survey.

Findings: The results obtained suggest that vocational training centres are an agent of significance within the RIS, contributing through its main lines of action (formal education, continuous training and company services) to improving the competitiveness of companies and to stimulating their innovation processes.

Research limitations: Although this paper has described the nature of the main mechanisms of relation between VT centres and industrial SMEs, there is a need for ongoing research to analyse the contribution of the educational system to innovation processes in industrial SMEs. For this purpose it would 
be interesting to measure how the skills of qualified workers and technicians coming from the VT system mesh with company innovation processes.

Originality/ value: The results of this study highlight a positive relationship between vocational training and innovation.

Keywords: SMEs, innovation, vocational training, regional innovation systems

Jel Codes: 120, J24, M53, 031

\section{I ntroduction}

According to a recent study by Cedefop (2010), vocational training, as well as reacting to changes in the environment, may also become a driving force for success and competitiveness for European economies and societies. The study confirms the importance of vocational training (VT) in contributing to sustaining economic development, stimulating capacity for business innovation and improving productivity. It also reveals that there is an urgent lack of empirical investigation capable of orientating the design and evaluation of public policies. This paper seeks to make a contribution to VT research that could act as an element of reflection for business, academic and public policy actors with responsibilities in the field of Education.

Even though the value of VT in economic and social development is widely recognised, Spain presents low VT indices in comparison with the main European countries. Only $18.7 \%$ of the active population in Spain have undertaken Vocational Training studies (2009). During the 2008/2009 academic year, the gross rate of Intermediate Level education in VT (Grado Medio, student ages 16-17), stood at 27.8\%, while the figure for Higher Level VT (Grado Superior, student ages 18-19) was $23.7 \%$. In most of the developed or developing countries, VT studies have a greater social and economic impact. In Germany and Austria, for instance, most Secondary Education students pursue studies in the VT field. In countries undergoing processes of socio-economic development, such as China, India, Russia or South Korea, almost $40 \%$ of people engaged in secondary studies opt for VT.

Within Spain, the Basque Vocational Training system proves to be one of the most developed experiences, due both to the greater relative impact of VT studies among the labour force (30.2\%, as compared an Spanish average of $18.7 \%$, see table 1 ), and to mechanisms implemented to improve quality and service to companies in 
this area. As can be seen in the table, the Basque region is above Spanish average in higher VT and other types of terciary education.

\begin{tabular}{|c|c|c|c|c|c|c|c|c|}
\hline & $\begin{array}{l}\text { Illitera } \\
\text { te }\end{array}$ & $\begin{array}{l}\text { Pre-primary } \\
\text { and primary }\end{array}$ & $\begin{array}{c}\text { Lower } \\
\text { secondary }\end{array}$ & $\begin{array}{c}\text { Upper } \\
\text { secondary } \\
\text { (general) }\end{array}$ & $\begin{array}{l}\text { Upper } \\
\text { second. } \\
\text { (Voc. } \\
\text { Training) }\end{array}$ & $\begin{array}{l}\text { Upper } \\
\text { second. } \\
\text { (Higher } \\
\text { Voc. } \\
\text { Training } \\
\end{array}$ & $\begin{array}{c}\text { Terciary } \\
\text { 1st } \\
\text { stage }\end{array}$ & $\begin{array}{l}\text { Terciary } \\
\text { 2nd } \\
\text { stage }\end{array}$ \\
\hline Andalusia & 0,8 & 17,5 & 33,8 & 12,1 & 8,7 & 8,6 & 8,7 & 9,7 \\
\hline Aragon & 0,2 & 14,6 & 22,5 & 17,0 & 11,8 & 10,1 & 10,9 & 12,9 \\
\hline Asturias & 0,0 & 9,8 & 27,6 & 14,4 & 10,3 & 12,7 & 12,2 & 13,0 \\
\hline $\begin{array}{c}\text { Illes } \\
\text { Balears }\end{array}$ & 0,5 & 13,6 & 35,6 & 18,9 & 8,8 & 6,7 & 8,0 & 7,9 \\
\hline Canarias & 0,5 & 17,9 & 29,8 & 17,3 & 9,1 & 8,9 & 7,7 & 8,9 \\
\hline Cantabria & 0,0 & 9,5 & 30,0 & 12,0 & 10,9 & 15,6 & 10,2 & 11,9 \\
\hline $\begin{array}{c}\text { Castilla-La } \\
\text { Mancha }\end{array}$ & 0,5 & 19,6 & 32,7 & 13,6 & 7,6 & 8,6 & 8,6 & 8,9 \\
\hline $\begin{array}{c}\text { Castilla- } \\
\text { Leon }\end{array}$ & 0,2 & 15,9 & 26,9 & 13,1 & 9,9 & 11,3 & 11,3 & 11,5 \\
\hline Catalonia & 0,5 & 18,2 & 24,6 & 15,1 & 9,1 & 10,2 & 8,8 & 13,5 \\
\hline Extremadura & 0,8 & 12,4 & 43,2 & 9,9 & 8,5 & 7,6 & 9,8 & 7,8 \\
\hline Galicia & 0,1 & 11,1 & 34,5 & 11,8 & 8,9 & 12,7 & 9,2 & 11,7 \\
\hline La Rioja & 0,3 & 11,7 & 27,1 & 14,1 & 9,4 & 13,9 & 10,4 & 13,1 \\
\hline Madrid & 0,4 & 10,3 & 21,3 & 22,1 & 6,0 & 7,5 & 10,5 & 21,9 \\
\hline Murcia & 1,2 & 18,2 & 32,5 & 13,6 & 8,9 & 7,6 & 7,9 & 10,1 \\
\hline Navarre & 0,1 & 9,2 & 26,3 & 14,2 & 11,4 & 14,3 & 11,3 & 13,2 \\
\hline $\begin{array}{l}\text { Basque } \\
\text { Country }\end{array}$ & 0,1 & 6,6 & 22,3 & 11,0 & 11,0 & 19,2 & 12,3 & 17,5 \\
\hline $\begin{array}{l}\text { Comunitat } \\
\text { Valenciana }\end{array}$ & 0,4 & 15,1 & 30,7 & 16,1 & 9,5 & 9,3 & 8,4 & 10,4 \\
\hline Ceuta & 1,7 & 15,7 & 32,2 & 16,8 & 6,7 & 7,5 & 10,1 & 9,3 \\
\hline Melilla & 4,2 & 23,0 & 28,0 & 9,8 & 5,3 & 5,1 & 11,8 & 12,9 \\
\hline Spain & 0,5 & 14,8 & 28,6 & 15,2 & 8,8 & 9,9 & 9,4 & 12,9 \\
\hline
\end{tabular}

Table 1. Labour force by level of education in Spanish regions, 2009 (\%)

In this paper we will concentrate on the contribution of VT centres to companies in the Basque Country. More specifically, this work sets out to provide answers to the following questions: What is the relation between VT centres and industrial SMEs?; What impact does it have on the activity of both agents?; How do companies assess the contribution made by VT centres?; How do VT centres contribute to the performance of the innovative SMEs?.

This document starts with a review of the concepts that permit the contextualisation of the relation between innovation and training within the regional innovation systems perspective (section 2 ). In the third section, a brief description is made of the vocational training system in the Basque Country, followed by the exposition, in the fourth section, of the methodology employed in gathering the data. The fifth section is devoted to setting out the results and the sixth to analytical discussion. The article concludes with the formulation of conclusions, acknowledgements and bibliographical references. 


\section{Vocational Training in the Regional I nnovation System}

The National Innovation System (NIS) perspective holds that social institutions influence economic action, in general, and innovation processes, in particular (Lundvall, 1992; Nelson, 1993; Edquist, 1997). The educational and training system is one of the social institutions that affect innovation.

Within the NIS perspective, regional level application ("regional innovation system", RIS) has won great acceptance in recent years (Braczyk et al., 1996; Cooke \& Morgan, 1998; Storper, 1997; Maskell \& Malmberg, 1999; Cooke, Gómez \& Etxeberria, 1997; Maskell, 2001; OECD, 2001). The RIS approach links in with a growing interest in the importance of the regional innovation environment, especially where small and medium companies (SMEs) are concerned.

From the Regional Innovation System perspective, innovation is conceived as a process of interactive learning within the company (communication and relations between departments, hierarchical levels and individuals in the organisation) and between it and other organisations (customers and suppliers, $R+D$ institutes, training centres, public agencies) (Lundvall, 1992). Internal and external interactive learning takes place within an institutional and cultural environment where aspects such as the following are of great importance: relationships between the public and the private sectors, relationships between the educational and productive systems, the framework of labour relations, and the financial system.

The institutional characteristics of a region and its infrastructures of knowledge are considered to be basic conditions of importance that may act as a stimulus to promote innovative activities (Isaksen \& Asheim, 2003). Different studies point to regions as being particularly significant for the exchange of tacit knowledge and for the provision of skilled labour, both of which are highly relevant mechanisms in the innovation processes of small companies (Asheim \& Coenen, 2005; Kauffmann \& Tödtling, 2003; Grotz \& Braun, 1997; Doloreux, 2003; Gebauer et al., 2005).

The interactive innovation model sets out from the premise of the fundamental importance of tacit knowledge (and its creation and transformation processes) in innovation, as well as of its specific and social-context dependent character. So, geographical proximity is of essential importance if innovation capabilities are to arise (Asheim \& Gertler, 2005: page 309-310). Trust, reciprocity, shared values, networks and norms speed up information transfer and the development of new knowledge. And, specifically, networks of inter-business and inter-organisational 
collaboration are particularly important in the case of SMEs, which make up the greater part of the European business fabric.

Our understanding is that, from the innovation system perspective, insufficient attention has been paid to the relation between the training system and the innovation system. As some authors have recently indicated, the innovation system is rooted within the production system and the "human resource development" system (Lundvall, 2002; Lundvall \& Christensen, 2003). Education systems and the job market are established at a national level, and play a crucial role in the construction of competencies and innovation capabilities.

As pointed out by Toner (2009) and Tether et al. (2005), among others, it is often forgotten that technical workers with intermediate qualifications intervene in the design, functioning and maintenance of products and processes, and therefore contribute (or can contribute) to innovation in companies. Innovative companies need a skilled workforce involved in the continuous improvement of processes and products (incremental innovation, "learning by doing").

The complementarity between education, training and innovation seems clear. Nonetheless, as Phillip Toner indicates (2009: page 61), “despite recognising the central role of higher level and more broadly distributed workforce skills in promoting innovation there has been little research within the field of innovation studies, or indeed other disciplines, on this topic".

Recently, some authors have highlighted the importance of the vocational and continuous training system in innovation (Rosenfeld, 1998; Curtain, 2004; Guthrie \& Dawe, 2004; Toner, Marceau, Hall \& Considine, 2004; Whittingham, Ferrier \& Trood, 2004; Tether, Mina, Consoli \& Gagliardi, 2005; Moodie, 2006; Bosch \& Charest, 2008; Ranga, Miedema \& Jorna, 2008; Toner, 2009). In an important report that Stuart Rosenfeld prepared for the Organisation for Economic Cooperation and Development (OECD), the author suggested that technical VT institutes were in a better position than universities to service SMEs, "in an era when employers are claiming that shortages of technicians are a greater problem than shortages of engineers" (ibid: page 35).

As Rosenfeld (ibid: page 6) points out, "the widely decentralized and applied technical colleges, in many regions, are the leading source of technological expertise and know-how and the core of regions' knowledge infrastructure. Technical colleges are particularly helpful to SMEs, which, as a result of the 
downsizing of industry over the past decades, are increasingly important to regional economies. Technical colleges are better positioned to reach SMEs than universities, consultants, and service agencies, many of which prefer not to bother with "knowhow" needs that may not be technologically challenging or of a scale that can be sufficiently profitable.

The same author proposes an interesting taxonomy of the missions of VT institutes, which encompass formal education, continuous training and support for SMEs in the implementation of new technologies, in innovation processes and in cooperation with other companies. Meanwhile, authors such as Ferrier et al. (2003) and Curtain (2004) stress the role performed by VT centres in the diffusion of technology.

In a qualitative study of Basque SMEs' innovation processes, we showed that, among the advantages obtained by SMEs from cooperation for innovation, attention must be paid to those deriving from their interaction with vocational training centres (Olazaran, Albizu \& Otero, 2009). Most of the 47 companies interviewed had close relationships with these centres.

Likewise, in the exploratory survey performed in 2008 upon a sample of 147 industrial SMEs in the Basque province of Gipuzkoa (Lavía, Otero, Olazaran \& Albizu, 2010), the assessment made by companies of vocational training infrastructures was very positive. As is shown in table 2, VT centres are, in general, very highly appreciated as cooperation partners, specially for smaller companies, reflecting the importance of this resource for SMEs. According to the data recorded in this survey, $18.3 \%$ of companies from Gipuzkoa cooperated with VT centres in innovation projects.

\begin{tabular}{|c|c|c|c|}
\hline Assessment averages ( 1 to 5 ) & Total & $\begin{array}{l}\leq 50 \\
\text { employees }\end{array}$ & $\begin{array}{l}>50 \\
\text { employees }\end{array}$ \\
\hline Companies in the fim's group & 3,81 & 3,72 & 3,89 \\
\hline $\begin{array}{l}\text { Suppliers of equipment, material components or } \\
\text { software }\end{array}$ & 3,67 & 3,57 & 3,80 \\
\hline Customers & 3,64 & 3,62 & 3,68 \\
\hline $\begin{array}{l}\text { Consultancy firms, engineering firms and/or other } \\
\text { services companies }\end{array}$ & 3,66 & 3,72 & 3,57 \\
\hline Universities & 3,29 & 3,38 & 3,18 \\
\hline Technology centres & 3,61 & 3,48 & 3,72 \\
\hline VT centres & 3,88 & 3,92 & 3,75 \\
\hline Clusters and/or cooperative research centres & 3,73 & 3,60 & 3,83 \\
\hline Sectoral business associations & 3,79 & 3,56 & 4,20 \\
\hline
\end{tabular}

Table 2. Industrial SMEs' assessment of innovation cooperation partners (Lavía, Otero, Olazaran \& Albizu, 2010) 


\section{Vocational Training in the Basque Country}

Vocational Training is a sphere of great importance in the educational system of the Basque Country, its mission being to relate formal and continuous training with the needs of regional industry. Accordingly, it fulfils a key function of furnishing the business fabric with skilled workers. In 2008, 25993 students were involved in formal VT education, while, as a result of the crisis, an upward trend in registrations is currently taking place. The system is serviced by 2177 teachers divided between 46 centres.

The speed with which those who hold diplomas in vocational training obtain their first job demonstrates the way these studies are oriented to the job market. The average time taken for those who finished VT in 2008 to secure their first employment was 26.7 days, an indicator that has gradually improved in recent years (in 2004 the figure stood at 36.9 days).

Apart from the relatively high proportion of the labour force with VT studies, from the significant penetration of the private education network (in Spain nearly $75 \%$ of students carry out their studies within the public network, while the percentage for the Basque Country drops to $53.7 \%$ ), and from its industrial orientation (42.5\% of students in the Basque Country against $31.8 \%$ in Spain), Basque vocational training displays three singular characteristics: continual institutional support, quality in the management of the centres and participation in continuous training.

One of the characteristics of the development of the VT system is the uninterrupted attention provided by regional authorities to this sphere of education. Indeed, since the mid-1990s different structures that are pioneering within the Spanish context have been created, such as the Tknika innovation centre, facilitating a progressive reinforcement of vocational training.

Another distinctive element of the VT system, in line with the proposals that emerged from the Copenhagen process, is the impetus provided by the regional government for the adoption of quality approaches comparable to those commonly used by industry and services. As a consequence, the establishment of different certifications, management systems and the obtaining of distinctions spread among the VT centres with notable results. According to the data provided by the regional government, 46 centres possess the ISO 9001 accreditation (International Organization for Standardization) in quality management; 18 centres the Gold Q, with over 500 points in the EFQM excellence model (European Foundation for Quality Management); 50 centres the Silver Q, with over 400 EFQM points; 10 
centres the ISO 14.001 in environmental management; 16 centres the Ecoskan distinction (Private label from Basque Country's IHOBE agency to reduce the environmental impact of organizations' activities); 1 centre the ISO 27001 in information security management system requirements; another meets the UNE 166.002 standard in $R \& D$ and innovation (from Aenor, Spanish standarization agency). This input has unquestionably stimulated a striking transformation of management structures, the modernisation of equipment, the transition to a new education offer and the development of continuous training.

The third element to highlight with regard to the contribution of vocational training centres to the current positioning of this sector within society is its growing commitment to the development of continuous and occupational VT (training for workers and for those unemployed). In the Basque Country the VT system has been performing an important role in covering this kind of training. The number of hours taught by the VT centres, the number of people trained and the funding received by the courses given have witnessed growth over recent years, in 2009 representing $50.36 \%$ of the total of teaching hours within the regional continuous training system, $51.9 \%$ of the people trained and covering $46.3 \%$ of the funding assigned for this category (information from Hobetuz Foundation for the Management and Development of Continuous Training in the Basque Country).

\section{Methodology and hypotheses}

The methodology employed in gathering the information for this study has been two-pronged. On the one hand, during the second semester of 2009 the qualitative field work was carried out, interviewing relevant actors in the vocational training system. To be precise, 13 in-depth interviews were held: 10 in VT centres, with the centre managers and heads of company relations, one interview in Tknika (Vocational Training and Permanent Learning Innovation Centre), and two with individuals occupying senior posts responsible for VT in the Basque Government (Government Deputy Minister for Vocational Training, 2006-2009; Director General of Vocational Training, 2009). The objective of this round of interviews was to ascertain how those in charge of the VT system perceived the activities developed and, in particular, their contribution to innovation processes in industrial SMEs. The interviews also enabled us to obtain information for the design of the questionnaire that was later put to the SMEs.

On the other hand, a survey of industrial SMEs was carried out in order to capture their perception of the service rendered by VT centres and to characterise the areas 
of collaboration with VT centres. The population was considered to be all industrial SMEs with registered offices in the Basque Country.

A random sample was selected $(\mathrm{N}=248)$ from among the population of industrial/manufacturing firms employing between 25 and 249 workers (CNAE93 codes 15 to 41 ). This is a sample upon a population of 1295 companies, which, from a statistical perspective, is considered to be a rather small population. The global sample size guarantees the statistical representativity of the company collective with a maximum sample error of $5.7 \%$ for estimates at a confidence level of $95.5 \%$ (under the assumption $p=q=0.5$ ). The sample was proportionally stratified per province and company size, with a final random selection of units in each stratum.

The questionnaire utilised for carrying out the field work, part of whose results are analysed in this article, was devised by the research team, taking as a reference: the objectives of the investigation, the literature analysed, the results of the qualitative research performed during the first stage of this project, and the limitations inherent to the type of survey chosen (telephone survey).

The survey was passed on to heads of human resources and training ( $85 \%$ of the cases), and in the remaining cases, to managers or directors. The field work was carried out between 10 and 24 June 2010. For purposes of analysis, and in order to further the aims of this work, innovative companies were considered separately from the non-innovative enterprises.

The general proposals which we would like to test are the following:

- The regional innovation environment and its infrastructures of knowledge, in particular the VT centres, act as a stimulous of SMEs' innovative activities

- The contribution of the VT centres to SMEs is best captured by the interactive innovation model

- The VT institutes develop a taxonomy of missions which encompasses formal education, continuous training and support for SMEs in the implementation of new technologies, in innovation processes and in cooperation with other companies 


\section{Results}

\section{Formal Training}

Adaptation of formal education programmes and subjects, based on relationships between SMEs and VT centres, makes it possible to better orientate the competencies of VT students to company needs. We analyse three aspects of this relation that affect the adaptation of human capital to companies, which are: incompany work training, curricular adaptation and the lease by companies of machinery and/or co-financing of the same to VT centres, for teaching purposes.

\section{In-Company Work Training}

In-Company Work Training refers to a compulsory work stay that VT students must carry out within a firm in order to obtain the vocational training degree. InCompany Work Training is a fundamental mechanism for companies and VT centres to become acquainted with one another and develop relations of trust. VT centre tutors visit companies and acquire a first-hand acquaintance of their activity, their training needs, and of the degree to which students' knowledge meets company requirements. Through this mechanism, VT centres can capture and channel information concerning changes that are taking place within the technological field in companies. The statistics also demonstrate that this is a powerful instrument for work placement since, in most cases, people who show a satisfactory attitude profile end up being taken on by companies.

In-Company Work Training tutors are, therefore, key figures through which relations and exchanges of information are channelled between VT centres and companies. Furthermore, through the relation established due to this system, companies have an opportunity to know the activity carried out by the centres, such as their continuous training offer, the equipment they have access to, the services they provide, etc.

As can be appreciated in table 3, almost $86 \%$ of the companies surveyed receive students within in-company training programmes. We feel that this fact is highly significant and indicates an important degree of relation between the companies and the VT educational system. Innovative companies are slightly above the average in this activity (3.8 percentage points). 


\begin{tabular}{|c|c|c|c|c|c|c|c|}
\hline & \multicolumn{6}{|c|}{$\begin{array}{c}\text { We receive students within I n-Company } \\
\text { Training Programmes }\end{array}$} \\
\hline & & \multicolumn{2}{|c|}{ Yes } & \multicolumn{2}{|c|}{ No } & \multicolumn{2}{|c|}{ Total } \\
\hline & & $\mathbf{N}$ & $\%$ & $\mathbf{N}$ & $\%$ & $\mathbf{N}$ & $\%$ \\
\hline \multicolumn{2}{|l|}{ TOTAL } & 180 & 85.7 & 30 & 14.3 & 210 & 100.0 \\
\hline \multirow{2}{*}{ I NNOVATI VE } & Yes & 126 & 86.9 & 19 & 13.1 & 145 & 100.0 \\
\hline & No & 54 & 83.1 & 11 & 16.9 & 65 & 100.0 \\
\hline
\end{tabular}

Table 3. Students within in-company training programmes

Assessment of this experience by the companies is really high (7.69/10), and the very slim percentage $(2.2 \%)$ of companies that have had unsatisfactory experiences is striking, while $22.2 \%$ evaluate the practices as an excellent tool (910 over 10$)$

\section{Curricular adaptation}

A result of the communication established between VT centres and companies is that adaptation of formal education programmes and subjects is facilitated. The VT centres interviewed undertake teaching cycles in specialities associated with the needs of companies in their local milieux. Along these lines, VT centres have developed a curricular specialisation strategy in terms of offering qualifications in relation with the profile of industry within the district, fulfilling their chief function of transferring skilled personnel to companies in the area.

Likewise, in the VT centres interviewed important efforts are made to adapt the content of education material to the specific needs of local companies. Although the main lines of the curriculum are defined by the Spanish central administration, the centres introduce adaptations and new content into the subject matter, in line with the demands of the companies they deal with.

The companies make a positive assessment (an average of 6.13 over 10) when asked if the VT centres transfer to their formal teaching programmes observations and suggestions for update and improvement made by companies. As may be observed from table 4 , this assessment is slightly more positive in innovative companies, very few of whom ( $12 \%$ of the innovative enterprises) give a "fail" mark to the centres for their sensitivity towards contributions made.

Responding to the requirements of personnel with growing skill levels demanded by industrial companies, some vocational training centres have begun to teach technical engineering or master degrees in collaboration with universities and companies. This also involves an effort from centres to capture students at source 
and prevent their "migration" towards universities and companies outside the district environment.

\begin{tabular}{|c|c|c|c|c|c|c|c|}
\hline & \multicolumn{6}{|c|}{$\begin{array}{l}\text { The VT centres transfer to their formal teaching } \\
\text { observations and suggestions for update and } \\
\text { improvement made by companies }\end{array}$} \\
\hline & & \multicolumn{2}{|c|}{ Assessment $<5$} & \multicolumn{2}{|c|}{ Assessment $\geq 5$} & \multicolumn{2}{|c|}{ Total } \\
\hline & & $\mathbf{N}$ & $\%$ & $\mathbf{N}$ & $\%$ & $\mathbf{N}$ & $\%$ \\
\hline \multicolumn{2}{|l|}{ TOTAL } & 23 & 13.1 & 143 & 86.1 & 166 & 100.0 \\
\hline \multirow[t]{2}{*}{ I NNOVATI VE } & Yes & 14 & 12.0 & 103 & 88.0 & 117 & 100.0 \\
\hline & No & 9 & 18.4 & 40 & 81.6 & 49 & 100.0 \\
\hline
\end{tabular}

Table 4. VT centres adapt their teaching programmes according to observations and suggestions for update and improvement made by companies

\section{Lease or financing of machinery for the VT centre by companies}

One of the most interesting collaboration experiences is produced in cases where companies lease machinery or participate in financing of the same as a support for teaching-learning processes. Thanks to this experience, which denotes a privileged relation between companies and VT centres, students become familiarised with the use of machinery and technologies that they will specifically find in the companies where they carry out their in-company training period and will, subsequently, be employed.

However, as can be seen in table 5, this is an incipient practice in Basque SMEs. Of the companies surveyed, $5.2 \%$ state that they have taken part in these initiatives, while there is a single percentage point rise for the proportion of innovative companies that have leased/financed machinery for VT centres.

\begin{tabular}{|c|c|c|c|c|c|c|c|}
\hline & \multicolumn{6}{|c|}{ We have leased/ financed machinery for the centre } \\
\hline & & \multicolumn{2}{|c|}{ Yes } & \multicolumn{2}{|c|}{ No } & \multicolumn{2}{|c|}{ Total } \\
\hline & & $\mathbf{N}$ & $\%$ & $\mathbf{N}$ & $\%$ & $\mathbf{N}$ & $\%$ \\
\hline \multicolumn{2}{|l|}{ TOTAL } & 11 & 5.2 & 199 & 94.8 & 210 & 100.0 \\
\hline \multirow[t]{2}{*}{ I NNOVATI VE } & Yes & 9 & 6.2 & 136 & 93.8 & 145 & 100.0 \\
\hline & No & 2 & 3.1 & 63 & 96.9 & 65 & 100.0 \\
\hline
\end{tabular}

Table 5. Lease or financing of machinery for the VT centre by companies

\section{Continuous Training}

Due to growing needs for the introduction of new technologies and processes by companies, training for workers and the unemployed is an activity that has witnessed a growth in its importance over recent years and will, foreseeably, 
continue to increase its weight in activities developed by VT centres. In fact, some centres that have seen a weakening in their role in regulated training (losing education programmes and/or being exposed to a growing fall in student registrations), declare that through continuous training they have discovered an opportunity to bolster the work of the centre with a view to the future. The VT centres interviewed coincide in asserting that the volume of hours spent on continuous and occupational training (i.e. training for active and unemployed workers respectively) has experienced a notable trend towards growth during the last years.

In the present context of economic crisis, the centres stress that companies have increased their training efforts. Indeed, training requested of VT centres by companies for staff subject to Labour Adjustment Plans has forcefully taken off thanks to funding facilitated to companies by government.

Continuous training courses are an important source of relation between VT centres and companies. Company technicians who attend these courses have a chance to get to become acquainted at close quarters with the centres, teachers and equipment they have at their disposal. Similarly, via the technicians, the teachers come to know the problems companies are facing in their daily activity and update their knowledge of business reality. Some interviewees point out that continuous training has contributed to raising the prestige of VT among companies in their milieu, as well as to strengthening links with them.

The centres, meanwhile, indicate that the training needs posed by the companies frequently fall within continuous training, although the content in time gradually comes to form part of the regulated training curriculum. The demands received from companies also mark out priorities in the acquisition of equipment that can provide back-up to the training provided.

\section{Modular Catalogue Continuous Training}

The so-called Vocational Training Modular Catalogue is the set of training modules associated with the different units of competency which are comprised within professional qualifications. It provides a common referent for the integration of vocational training offers that makes it possible to capitalise and encourage learning through life (INCUAL, 2008). VT centres appear as suppliers of considerable importance in continuous training services for the companies they 
associate with: $44.3 \%$ of the companies surveyed send their workers to receive continuous training offered within the Modular Catalogue in the VT centre network.

With regard to the continuous training that companies obtain from centres via Modular Catalogue courses, we detect (table 6) that the innovative enterprises have greater recourse to this training solution than do the non-innovative firms (47.6 versus $36.9 \%)$.

\begin{tabular}{|c|c|c|c|c|c|c|c|}
\hline & \multicolumn{6}{|c|}{$\begin{array}{c}\text { Our workers attend the centre to receive MCCT } \\
\text { courses }\end{array}$} \\
\hline & & \multicolumn{2}{|c|}{ Yes } & \multicolumn{2}{|c|}{ No } & \multicolumn{2}{|c|}{ Total } \\
\hline & & $\mathbf{N}$ & $\%$ & $\mathbf{N}$ & $\%$ & $\mathbf{N}$ & $\%$ \\
\hline \multicolumn{2}{|l|}{ TOTAL } & 93 & 44.3 & 117 & 55.7 & 210 & 100.0 \\
\hline \multirow{2}{*}{ I NNOVATI VE } & Yes & 69 & 47.6 & 76 & 52.4 & 145 & 100.0 \\
\hline & No & 24 & 36.9 & 41 & 63.1 & 65 & 100.0 \\
\hline
\end{tabular}

Table 6. Modular Catalogue Continuous Training (MCCT)

Continuous training provided by VT centres for SME workers is very highly rated by companies ( 7.38 over 10 ). No company gives an unsatisfactory appraisal of this type of training in VT centres. The company positioning is so clear and generalised in this dimension that significant differences in the average assessment have not been observed where innovative companies are concerned.

\section{Tailored continuous training}

Some VT centres with a higher degree of customer orientation are becoming suppliers of companies' tailored training solutions. That is, they are setting themselves up as agents who, on receiving the requests of local companies with regard to their training needs, channel and manage a training offer that includes their own as well as outside trainers, whom they coordinate around the specific training demand made by the companies.

Of the companies that associate with VT centres, $23.8 \%$ have declared that they use them to obtain tailored continuous training (table 7). In addition, the immense majority of these companies $(80.0 \%)$ also send their workers on modular catalogue training courses. As can be perceived from the table below, innovative companies have far greater recourse to VT centres in order to carry out á la carte continuous training (29.7\% versus $10.8 \%$ in the case of non-innovative enterprises). There is a significant relationship (chi-square $s i g=0.003$ ) between carrying out a la carte continuous training and being an innovative company. 


\begin{tabular}{|c|c|c|c|c|c|c|c|}
\hline & \multicolumn{6}{|c|}{ We have carried out TCT with the VT centres } \\
\hline & & \multicolumn{2}{|c|}{ Yes } & \multicolumn{2}{|c|}{ No } & \multicolumn{2}{|c|}{ Total } \\
\hline & & $\mathbf{N}$ & $\%$ & $\mathbf{N}$ & $\%$ & $\mathbf{N}$ & $\%$ \\
\hline \multicolumn{2}{|l|}{ TOTAL } & 50 & 23.8 & 160 & 76.2 & 210 & 100.0 \\
\hline \multirow{2}{*}{ I NNOVATI VE } & Yes & 43 & 29.7 & 102 & 70.3 & 145 & 100.0 \\
\hline & No & 7 & 10.8 & 58 & 89.2 & 65 & 100.0 \\
\hline
\end{tabular}

Table 7. Tailored continuous training (TCT)

The average assessment of VT centres as continuous tailored training suppliers is 7.48 points over 10 , rising to 7.63 in the case of innovative companies. Industrial SMEs that utilise tailored continuous training exhibit a high intensity of relations and of trust-toward the centre, as $88 \%$ of the companies that carry out this kind of continuous training already have 3 or more different types of relationships with the VT centres (e.g., receiving students for in-company training periods, hiring from job pools, Modular Catalogue training, use of facilities, etc.).

\section{Services directly geared to company innovation}

The people interviewed are in agreement when they point out that, traditionally, VT centres have provided consultation and/or services of a technological nature to companies within their remit. Through the relation of trust and proximity between both agents, developed in different ways (in-company training programme links, continuous training courses, associations of old pupils, presence of companies on the centre's governing bodies, district-level discussion forums), various formulas for collaboration have been suggested by the companies in this section: fundamentally, for companies to use the infrastructure belonging to the centres, and to collaborate in innovation projects, whether that be in management or within the technological sphere.

\section{Use of technological infrastructure}

VT centres say that they make available to companies, on request, equipment and personnel to which they have access, for the solution of different kinds of technological problems (e.g., new design elements, the manufacture of tools, improvements in processes, metrologies, experiments and trials with materials). The opportunity of using equipment of a good technological level, sometimes acquired through regional public funding and also, on other occasions, due to the collaboration of companies, is one of the planks for VT centres' service provision to 
companies and constitutes a relevant regional infrastructure for innovation in industrial SMEs that, as a rule, suffer from a lack of resources to be able to carry out actions of this kind and remain at a remove from interlocution with other actors such as technology centres or universities.

The data from this survey (table 8 ) show that $18.1 \%$ of companies have recourse to VT centres in order to use their infrastructure and are very satisfied with the service. Centre facilities and equipment are used slightly more often in innovative companies (20\%), with a percentage difference of use of 6.2 percentage points over non-innovative enterprises (13.8\%).

\begin{tabular}{|c|r|r|r|r|r|r|r|}
\cline { 3 - 8 } & \multicolumn{6}{|c|}{ We use their facilities/ machinery to carry out } \\
experiments, trials, etc.
\end{tabular}

Table 8. Use of VT centres' technological infrastructure

\section{$\underline{\text { Innovation projects }}$}

Over recent years, the centres have been making an effort to formalise and systematise provision of the technical aid that they offer companies. To this end different projects have arisen aimed at offering SMEs access to innovation and continuous improvement in their key processes, providing them, via the centres, with technical support, tools, methodologies and training suited to their needs.

The people interviewed coincide in affirming that the niche of action for vocational training centres is mainly to be found in micro and small companies within the environment of the local district, which are the firms that have fewer capabilities of innovation and are not reached by $R+D$ infrastructure (technology centres and universities, in the main). Cooperation with these enterprises is not attractive for these technology agents, who show a preference for working on projects with larger companies, involving longer time periods covering innovation collaborations, making them more attractive from the perspective of the economic sums allocated and because of their greater technical content. With innovation projects it can be appreciated that the VT centres are adopting a more proactive attitude in the relations they hold with companies. Similarly, this VT centre-company collaboration is considered to redound in quality and in the improved training offered by the 
centres. Two kinds of collaboration can be distinguished in innovation projects: management improvement projects and technical innovation projects.

As shown in table 9, of the companies surveyed, $8.1 \%$ have a VT centre collaborating in management/organisation improvement programmes, with a proportional difference of three percentage points between the innovative and the non-innovative enterprises that collaborate with VT centres in these projects. The assessment made of this kind of collaboration by the companies stands at 7.19/10 points, with no differences in average evaluation between companies vis-à-vis their behaviour in terms of innovation.

\begin{tabular}{|c|c|c|c|c|c|c|c|}
\hline & \multicolumn{6}{|c|}{$\begin{array}{c}\text { They collaborate with us as assessors/ consultants in } \\
\text { management improvement/ organisational } \\
\text { improvement programmes }\end{array}$} \\
\hline & & \multicolumn{2}{|c|}{ Yes } & \multicolumn{2}{|c|}{ No } & \multicolumn{2}{|c|}{ Total } \\
\hline & & $\mathbf{N}$ & $\%$ & $\mathbf{N}$ & $\%$ & $\mathbf{N}$ & $\%$ \\
\hline \multicolumn{2}{|l|}{ TOTAL } & 17 & 8.1 & 193 & 91.9 & 210 & 100.0 \\
\hline \multirow{2}{*}{ I NNOVATI VE } & Yes & 13 & 9.0 & 132 & 91.0 & 145 & 100.0 \\
\hline & No & 4 & 6.2 & 61 & 93.8 & 65 & 100.0 \\
\hline
\end{tabular}

Table 9. Collaboration as assessors/consultants in management improvement

In addition, $6.7 \%$ of the companies in this sample have undertaken some formal technical innovation project with VT centres, a proportion that rises to $9.7 \%$ in the innovative companies, which represent $100 \%$ of the companies that develop this type of collaboration (table 10). The company assessment of this collaboration is, in this case, $6.79 / 10$ points.

\begin{tabular}{|c|r|r|r|r|r|r|}
\cline { 3 - 9 } & \multicolumn{6}{|c|}{ They collaborate with us in (formal) technical } \\
innovation projects
\end{tabular}

Table 10. Collaboration in technical innovation projects

\section{Discussion}

The evidence encountered in this research makes it clear that VT centres are actors that provide the Regional Innovation System with valuable human and intellectual capital and that industrial SMEs are sensitive to the performance of VT centres in the Basque Country, both because of the high proportion of companies that state 
that they maintain relations with VT centres, and because of the genuinely positive assessment they make of their contribution.

Geographical proximity is a key factor in the VT centre-company relationship. High specialisation in regional industry has, in turn, favoured specialisation in VT centres. The latter respond offering education programmes adapted to the qualification profiles most in demand in the district where they are located. But, apart from each VT centre's specialisation map, as a result of the VT centre-SME relation, a modification of the content of the training provided in the centres is brought about due to the inputs they receive from local companies.

So, in this close relation between VT centres and companies, the specificity of knowledge acquires importance in terms of its sectoral utilisation. A specific curricular specialisation (mechanical manufacture, welding or programmable automata, for instance) is adapted to the particular needs of companies in a district (e.g. machine tools or elevating machinery) through teaching-learning processes guided by the communication mechanisms developed between VT centres and companies.

The trust relations that exist between these agents, facilitating such communication, have different foundations:

a) The fact that in-company student training is a compulsory component of VT curricula has generated an interesting and dynamic route of connection between VT centres and companies. Work placement tutors have an opportunity to be in contact with company tutors and to directly evaluate the degree to which studies are adapted to company needs. Almost $86 \%$ of companies make use of in-company student training, which becomes an efficient company preselection mechanism (Basterretxea et al., 2002, González, Cueto \& Mato, 2005), whilst constituting a relevant information source for $\mathrm{VT}$ centres and a powerful tool for student training (Rodríguez, 2005). In addition, company evaluation of in-company training programmes is very high (7.69 over 10), providing a clear picture of the great utility this activity yields them.

b) The high participation rate of VT centres as continuous training suppliers, either through the Modular Catalogue or through the design and provision of tailored training. Continuous training enables VT centres to gain in visibility and prestige vis-à-vis their companies of reference, impacting favourably on the reinforcement of relations with companies, in addition to constituting a complementary channel 
through which companies and centres are brought into meaningful contact. The workers have access to the centre's classrooms and facilities, allowing teaching staff involved in continuous training to be constantly retrained as they tackle the real problems affecting companies. The frequent contact produced between company technicians and VT teachers in continuous training, in within-company student training programmes and, to a lesser degree, through innovation services, facilitates transfer of the tacit component of technological knowledge between the actors, beyond its explicit contents.

The training impetus of VT teachers participating in continuous training has the added consequence of upgrading and improving the formal education curriculum, raising the level of quality. As the results of this investigation have demonstrated, companies are aware that VT centres adapt education content in line with the inputs received by VT centres. Of the companies that have relationships with VT centres, $86 \%$ assess this item positively. This dimension has substantially improved over the last decade, if the results are compared with earlier work by Basterretxea et al. (2002), where some scepticism was shown by companies with regard to this question.

Continuous training needs map out priorities for the acquisition of equipment that will subsequently be used in this training and, by extension, in the formal education area, thus contributing to improving the human and intellectual capital of companies. In another regard, and as yet only incipiently, a small number of SMEs (5.2\%) contribute to VT centres through co-financing or the lease of machinery, practices that encourage a better adaptation of student skills to company needs.

c) Participation of companies in different bodies dealing with information and the adoption of decisions that affect vocational training centres (governing councils - in the case of cooperatives-, board of trustees -in the case of foundations-, old student associations, district development agencies). These mechanisms of communication tend to be more solid in private centres that, as was seen in the third section, have a relatively high presence in the Basque Country. Interlocution with companies allows the centres to clearly set their referents of action. This aspect was also noted by Basterretxea et al. (2002).

Continuous training is the area where the most appreciable differences occur in the behaviour of industrial SMEs. In this dimension an important advance has also taken place compared to the situation a decade ago which Basterretxea and colleagues referred to. Innovative SMEs utilise continuous training to a far greater 
degree than do non-innovative enterprises: there is a difference of 10 percentage points in Modular Catalogue Continuous Training (44.3\% de innovative companies that are involved in MCCT versus $36.9 \%$ of non-innovative enterprises) and of 19 points in Tailored Continuous Training $29.7 \%$ of innovative companies that use TCT versus $10.8 \%$ of non-innovative enterprises). In addition, the assessment of continuous training made by innovative SMEs is very high: (7.38 in the case of MCCT and 7.63 for TCT). These figures suggest that, in the sample of companies analysed, there is a positive relationship between innovation and continuous training.

Similarly, differential behaviour occurs in SMEs in relation to the demand for VT centres to provide technology services. Although, as we have seen, various initiatives have recently been taken to formalise this line of activity in the centres, the demand for such services is still fairly low. Of the innovative companies, $20 \%$ use the technical infrastructures of VT centres (with an assessment rating of 7.63 points) against $13.8 \%$ of non-innovative SMEs. And $9.7 \%$ of innovative companies collaborate in technical innovation projects (only companies that consider themselves to be innovative have asked VT centres to carry out innovation projects). In this regard there appears to be a gap between the declarations of the heads of VT centres (who stress the efforts they make to boost this line of activity, which is, in their view, strategic) and the evidence concerning the use of these services, which involves only a small minority of firms concentrated around a few cases. Company assessment of these, while clearly positive (6.79), also falls below the evaluation given for other collaboration activities developed with the centres, suggesting the existence of possible areas of improvement for the VT centres.

Over recent years, thanks to financing from continuous training, from the development of projects with companies, and from regional government programmes, some leading VT centres have set up specialised structures of relation with companies (basically, units for the transfer of knowledge to companies). In general, these structures, which are managed in line with quality criteria (either because their processes are certified or because they follow the EFQM model), can incorporate a wide range of services: in-company student training programme management, Dual Training programmes, innovation projects, monitoring and technology prospecting, diagnoses of training needs, tailored continuous training management, etc. These services, where they exist, act as a single window that centralises, accordingly, management of information from the business world, minimising the possibility of such information being lost and helping it to be used efficiently. In our opinion, this qualitative step in the development of VT centres is, 
above all, a consequence of the intensification of the weight of continuous training, which has produced the need to set up a body specialised in attending to company needs.

One clear reason why vocational training has made an important contribution to the productive fabric of the Basque Country is the support received from public policies. The regional governments bodies are one of the main RIS actors, and in the Basque case they have wielded significant weight in the development of that system. Over various legislatures, through the Basque Government, with competences in Education, but also with economic support from the provincial administrations, notable efforts have been made to modernise and revitalise vocational training, investing it with prestige. One of the concrete actions that we find most differentiating when compared to Vocational Training in other regions is the creation of the Innovation Centre Tknika (cf. Section 3). This initiative has undoubtedly raised the level of management and quality of service offered by VT centres.

While all these advances open the way for vocational training to make great strides in the Basque Country, offering increasingly better service to companies and more solid training to students, and becoming a reference within Spain, there are some questions that deserve attention from government and social actors and ought to be acted upon by them in order to improve the current situation.

Although the prestige of VT has expanded over recent years, work should be put into building the way these studies are perceived by society and companies. The latter have identified the lack of suitably trained staff as one of the principal blocks against growth. In addition, the delocalisation processes that are taking place within Basque industry too - mean that the productive activities that remain have a greater value added component. This point to a need to employ people with increasing skill levels within the industrial sphere. Meanwhile, the educational system is suffering from alarming levels of academic unpreparedness and school dropout, producing hosts of individuals holding qualifications that do not fit with the productive economy. From our point of view it would be beneficial, even more so in times of crisis, to maintain the support provided by the public administrations to this part of the educational system that is so directly integrated within the Regional Innovation System. 


\section{Conclusions}

This article shows that the VT centre network is a relevant RIS agent in the Basque Country, contributing through its main action lines (formal education, continuous training and company services) to improving the competitiveness of companies and to encouraging their innovation processes.

In-company student training schemes, which were institutionalised after the Spanish VT reform of the 1990s, have been a key factor for the development of regular VT centre/company relationships. Based on those relationships, the VT centres make improvements in the formal education curriculum in order to adapt it to company needs, as well as to emerging new technologies.

More evolved forms of relationships involve an increase in the offer of continuous training courses (both catalogue-based and tailored to specific needs) from the VT centres to the companies. Right now, explicit and tacit knowledge transfer processes related to continuous training seem to be a key element in advanced VT centres/companies relations.

Overall the relation operating between VT centres and industrial SMEs seems quite satisfactory, and the mechanisms of communication and collaboration established between them appear quite fluid. Consequently, both agents benefit from the experience: the companies can count on skilled human capital and infrastructures that are increasingly better adapted to their needs and the VT centres can rely on feedback and business support that enable them to improve the process of transferring technological knowledge to companies.

Where company innovation processes are concerned, there is a notable contribution by VT centres to innovative companies, which is grounded, fundamentally, in continuous training and, to a lesser degree, in technical infrastructure and technology services. Overall this study highlights the positive relation between training and innovation.

Although this paper has described the nature of the main mechanisms of relation between VT centres and industrial SMEs, there is a need for ongoing research to analyse the contribution of the educational system to innovation processes in industrial SMEs. For this purpose it would be recommendable to measure how the skills of people who emerge from the VT system mesh with company innovation processes. 


\section{Acknowledgments}

This research has been carried out with funding from the government of Gipuzkoa (Diputación Foral de Gipuzkoa, S\&T Network Programme), the Basque Government (Research Group Grant) and the Spanish Ministry of Science and Innovation (Project no. CSO2008-06520-C02-01).

We wish to express our thanks to the people who kindly responded to our request for collaboration in giving us their viewpoint concerning the functioning of the VT system and the relations between VT centres and companies. We likewise thank the companies that took the time to reply to the questionnaire put to them.

Finally, we wish to express our acknowledgement to the anonymous reviewers and editor for their attention, kind comments and helpful contributions.

\section{References}

ASHEIM, B.; GERTLER, M. (2005). The Geography of Innovation: Regional Innovation Systems, in FAGEBERG, J., MOWERY, D.; \& NELSON, R. (Eds.), The Oxford Handbook of Innovation. Oxford: Oxford University Press: 291-317.

ASHEIM, B.T.; COENEN, L. (2005). Knowledge bases and regional innovation systems: comparing Nordic clusters. Research policy, 34(8): 173-190. http://dx.doi.org/10.1016/i.respol.2005.03.013

BASTERRETXEA, I.; GONZÁLEZ, A.; SAIZ, M.; SIMÓN, L. (2002). Colaboración entre los centros de Formación Profesional y las empresas en la Comunidad Autónoma Vasca. Leioa: Editorial Service of the University of the Basque Country.

BOSCH, G.; CHAREST, J. (2008). Vocational training and the labour market in liberal and coordinated economies. Industrial Relations Journal, 39(5): 428-447. http://dx.doi.org/10.1111/j.1468-2338.2008.00497.x

BRACZYK, H., COOKE, P.; HEIDENREICH, R. (Eds.) (1996). Regional Innovation Systems. The Role of Governances in a Globalized World. London: University College London Press.

CEDEFOP (2010). La modernización de la formación profesional. Information note. July. Luxembourg: European Union Publications Office. http://www.cedefop.europa.eu/EN/Files/9013_es.pdf 
COOKE, P., GÓMEZ, M.; ETXEBARRIA, G. (1997). Regional Innovation Systems: Institutional and Organizational Dimensions. Research Policy, 26(4-5): 475-491. http://dx.doi.org/10.1016/S0048-7333(97)00025-5

CURTAIN, R. (2004). Innovation and Vocational Education and Training, in DAWE, S. (Ed.). Vocational Education and Training and Innovation: Research Readings, Adelaide, SA, Australia: National Centre for Vocational Education Research (NCVER): 42-58.

DOLOREUX, D. (2003). Regional innovation systems in the periphery: the case of Beauce in Quebec (Canada). International Journal of innovation management, 7(1): 67-94. http://dx.doi.org/10.1142/S1363919603000738

EDQUIST, C. (1997). Systems of Innovation: Technologies, Institutions, and Organizations. London: Pinter.

FERRIER, F.; TROOD, C.; WHITTINGHAM, K. (2003). Going boldby into the future: a series of case studies of co-operative research centres and their relationships with the VET sector. Leabrook: National Centre for Vocational Education Research. http://www.ncver.edu.au/publications/939.html

GEBAUER, A., WOON NAM, C.; PARSCHE, R. (2005). Regional technology policy and factors shaping local innovation networks in small German cities. European Planning Studies, 13(5): 661-683. http://dx.doi.org/10.1080/09654310500139301

GONZÁLEZ, M.C.; CUETO, B.; MATO, J . (2006). El papel de la Formación en Centros de Trabajo (FCT) en la inserción laboral de los titulados de ciclos formativos: el caso de Asturias, Revista de Educación, 341: 337-372.

GROTZ, R.; BRAUN, B. (1997). Territorial or transnational networking: spatial aspects of technology oriented cooperation within the German mechanical Engineering Industry. Regional Studies, 31(6): 545-557. http://dx.doi.org/10.1080/00343409750131686

GUTHRIE, H.; DAWE, S. (2004). Overview, in DAWE, S. (Ed.). Vocational Education and Training and Innovation: Research Readings, Adelaide, SA, Australia: National Centre for Vocational Education Research: 10-19.

INCUAL. INSTITUTO NACIONAL DE CUALIFICACIONES (2008), Catálogo Modular de Formación Profesional. Madrid: Secretaría General Técnica del Ministerio de Educación, Política Social y Deporte. 
ISAKSEN, B.T.; ASHEIM, A. (2003). SMEs and the regional dimension of innovation, in ASHEIM, B.T.; ISAKSEN, A.; NAUWELAERS C. \& TÖDTLING, F. (Eds.). Regional innovation policy for small-medium enterprises. Cheltenham: Edwar Elgar: 21-46.

KAUFFMANN, A.; TÖDTLING, F. (2003). Innovation pattern of SMEs, in ASHEIM, B.T.; ISAKSEN, A.; NAUWELAERS C. and TÖDTLING, F. (Eds.). Regional innovation policy for small-medium enterprises. Cheltenham: Edwar Elgar: 78115.

LAVÍA, C., OTERO, B., OLAZARAN, M.; ALBIZU, E. (2010). Innovación y territorio: una encuesta a pequeñas y medianas empresas (pymes) industriales. Revista Internacional de Sociología, 69 (2): 461-486. http://dx.doi.org/10.3989/ris.2009.11.06

LUNDVALL, B.A. (Ed.) (1992). National Systems of Innovation: Towards a Theory of Innovation and Interactive Learning. London: Pinter.

LUNDVALL, B.A. (2002). Innovation, Growth and Social Cohesion: The Danish Model. Cheltenham UK: Edward Elgar.

LUNDVALL B.A.; CHRISTENSEN J.L. (2003). Broadening the Analysis of Innovation Systems - Competition, Organisational Change and Employment Dynamics in the Danish System, in CONCEICAO P., HEITOR M.V. and LUNDVALL B.A., Innovation, Competence Building and Social Cohesion in Europe. Towards a Learning Society. Cheltenham UK: Edward Elgar: 144-179.

LUNDVALL, B.A. (1992). National Systems of Innovation: Towards a Theory of Innovation and Interactive Learning. London: Pinter.

MASKELL, P.; MALMBERG, A. (1999). Localised learning and industrial competitiveness. Cambridge Journal of Economics, 23(2): 167-186.

MASKELL, P. (2001). Social capital, innovation and competitiveness, in Baron,S.; FIELD, J. \& SCHULLER, T. (Eds.). Social Capital: Critical perspectives. Oxford: Oxford University Press: 111-123.

MOODIE, G. (2006). Vocational education institutions' role in national innovation. Research in Post-compulsory Education, 11(2): 131-140. http://dx.doi.org/10.1080/13596740600768901

NELSON, R.R. (Ed.) (1993). National Innovation Systems: A Comparative Analysis. Oxford: Oxford University Press. 
OECD (2001). The Well-being of Nations, The Role of Human and Social Capital. Paris: OECD.

OLAZARAN, M.; ALBIZU, E.; OTERO, B. (2009). Innovación en las pequeñas y medianas empresas industriales guipuzcoanas ('Innovation in the industrial SMEs of the Guipuzcoa province') Bilbao: University of the Basque Country Publishing Services.

RANGA, L.M.; MIEDEMA, J.; J ORNA, R. (2008). Enhancing the innovative capacity of small firms through triple helix interactions: challenges and opportunities. Technology Analysis and Strategic Management, 20(6): 697-716. http://dx.doi.org/10.1080/09537320802426408

RODRíGUEZ, M. (2005). La Formación en Centros de Trabajo: Datos sobre su desarrollo en la familia Administración en la Comunidad de Madrid. Revista Complutense de Educación, 16(1): 255-288.

ROSENFELD, S. (1998). Technical colleges, technology deployment and regional development. Modena, Italy: OECD.

STORPER, M. (1997). The regional economy. New York: Guilford Press.

TETHER, B.; MINA, A.; CONSOLI, D.; GAGLIARDI, D. (2005). A Literature Review on Skills and Innovation. How Does Successful Innovation Impact on the Demand of Skills and How Do Skills Drive Innovation?. Manchester: ESRC Centre for Research on Innovation and Competition (CRIC), University of Manchester.

TONER, P. (2009). Workforce Skills and Innovation: An Overview of Major Themes in the Literature. Paris: OCDE.

TONER, P.; MARCEAU, J.; HALL, R.; CONSIDINE, G. (2004). Innovation agents: Vocational education and training skills in the present and future Australian innovation system, in DAWE S (Ed.), Vocational Education and Training and Innovation: Research Readings. Adelaide, SA, Australia: National Centre for Vocational Education Research: 84-105.

WHITTINGHAM, K.; FERRIER, F.; TROOD, C. (2004). Vocational education and training and the commercialisation of Australian research, in DAWE, S. (Ed.). Vocational Education and Training and Innovation: Research Readings. Adelaide, SA, Australia: National Centre for Vocational Education Research: 106-117. 
Intangible Capital, 2011 (www.intangiblecapital.org)

\section{(c)}

Article's contents are provided on a Attribution-Non Commercial 3.0 Creative commons license. Readers are allowed to copy, distribute and communicate article's contents, provided the author's and Intangible Capital journal's names are included. It must not be used for commercial purposes. To see the complete licence contents, please visit http://creativecommons.org/licenses/by-nc/3.0/es/ 